\title{
Pengembangan perangkat pembelajaran matematika dengan pendekatan kontekstual budaya Lombok
}

\section{Juz'an Afandi ${ }^{1}$}

Abstrak: Budaya merupakan hal yang dekat dengan kehidupan manusia termasuk siswa. Budaya merupakan salah satu hal yang dapat dijadikan media untuk dapat belajar oleh siswa, sekaligus mempelajari budaya itu sendiri. Seseorang akan belajar dengan baik jika hal yang dipelajari adalah hal yang dekat dengan lingkungannya salah satunya adalah budaya. Penelitian ini bertujuan untuk menghasilkan dan mendeskripsikan karakateristik perangkat pembelajaran matematika SMP dengan pendekatan kontekstual budaya Lombok berorientasikan prestasi belajar matematika dan apresiasi nilai budaya bangsa yang valid, praktis, dan efektif. Penelitian ini merupakan penelitian pengembangan dengan model pengembangan ADDIE (Analysis, Design, Development, Implementation, dan Evaluation). Hasil penelitian menunjukkan bahwa perangkat pembelajaran yang dikembangkan valid ditunjukkan dengan hasil penilaian RPP dan LKS berada pada kategori "baik". Perangkat pembelajaran yang dikembangkan praktis ditunjukkan dengan hasil penilaian guru, penilaian siswa, dan observasi keterlaksanaan pembelajaran berada pada kategori "baik". Perangkat pembelajaran yang dikembangkan efektif ditinjau dari prestasi dan apresiasi nilai budaya bangsa. Perangkat pembelajaran matematika yang dikembangkan memiliki karakteristik sebagai berikut: (a) kegiatan pembelajaran memuat langkah-langkah pendekatan kontekstual budaya Lombok yang terdiri dari relating, experiencing, applying, cooperating, dan transferring, (b) memuat konteks budaya Lombok, dan (c) menggunakan instrumen untuk mengukur apresiasi nilai budaya bangsa.

Kata kunci: Perangkat Pembelajaran; Pendekatan Kontekstual; Budaya Lombok; Prestasi Belajar; Apresiasi Nilai Budaya

Abstract: Culture is the thing close to a human life including students. Culture is one of the things that can be used as a media to be studied by students while learning about the culture itself. The students will

\footnotetext{
${ }^{1}$ Universitas Negeri Yogyakarta, Indonesia, juzanafandi@gmail.com
} 
learn best when they have something familiar with their environment, one of them is culture. The aim of this research is to develop and describe the characteristics of mathematics instructional kits for junior high school with contextual approach of Lombok culture oriented to the learning achievement and appreciation of the cultural values which is valid, practical, and effective. This study is developmental research that uses ADDIE's model (Analysis, Design, Development, Implementation, and Evaluation). The research shows that the developed instructional kits are valid. It is shown by validation result of lesson plan and student's worksheet is in good category. The instructional kits that have been developed are practical shown by result of teacher's assessment, student's assessment, and implementation of learning in good category. They are also effective based on student's mathematics achievement and appreciation of cultural values. The mathematics instructional kits have the following characteristics: (a) Learning activities contains steps based on the contextual approach of Lombok culture which consist of relating, experiencing, applying, cooperating, and transferring; (b) It contains Lombok cultural context; and (c) It uses instruments to measure the appreciation of the cultural values.

Keywords: Instructional Kits; Lombok Culture; Contextual Approach; Learning Achievement; The Appreciation of Cultural Values

\section{A. Pendahuluan}

Pendidikan memiliki peranan yang sangat penting dalam pembangunan sumber daya manusia. Keberhasilan dari pendidikan, khususnya pendidikan formal sangat ditentukan salah satunya oleh proses pembelajaran di sekolah. Menurut Permendikbud Nomor 103 (Mendikbud, 2014), prinsip pembelajaran yang ideal ialah ketika siswa dapat mencari tahu sendiri dan belajar berbasis aneka sumber belajar. Belajar tidak hanya tentang guru menjelaskan dan siswa menerima. Pembelajaran yang baik ialah pembelajaran yang bersifat student oriented bukan teacher oriented. Guru bukanlah satu-satunya sumber dalam belajar, namun sangat banyak sumber yang dapat dijadikan acuan dalam belajar. Seseorang tentu akan dapat belajar dengan baik jika materi yang dipelajari adalah hal yang dekat dengan kehidupan mereka. Jadi, lingkungan merupakan sumber yang sangat baik bagi siswa dalam belajar. 
Lingkungan tersebut dapat berupa kebiasaan, lingkungan sosial, budaya setempat, dan lain sebagainya.

Proses pembelajaran yang baik tentu memiliki persiapan yang baik pula dari guru, yakni berupa kesiapan dalam mengajar yang terlihat dari kesiapan perangkat pembelajaran. Perangkat pembelajaran seperti RPP, LKS, dan sebagainya hendaknya mampu membelajarkan siswa serta mampu mengarahkan siswa untuk dapat mengkonstruksi pengetahuannya. Matematika yang pada umumnya bersifat abstrak, sangat membutuhkan cara, strategi, dan arahan dalam belajar yang mampu membuat matematika lebih konkret bagi siswa. Oleh karena itu, perangkat pembelajaran matematika yang dibuat oleh guru hendaknya lebih bersifat kontekstual, sehingga dapat membantu siswa untuk memahami materi matematika yang bersifat abstrak.

Proses pembelajaran yang baik hendaknya juga mampu memberikan perubahan perilaku dari siswa. Hasil belajar yang baik tidak hanya sematamata dilihat dari aspek kognitif saja, namun perilaku dan sikap siswa, termasuk di dalamnya apresiasi budaya dan cinta tanah air. Hal demikian jika diterapkan di sekolah sebagai tempat proses pembelajaran formal, akan membuat sekolah menjadi tempat yang mampu memberikan bekal kepada siswa untuk siap menghadapi kehidupan global. Hal ini dikarenakan di dalam proses pembelajaran di sekolah, tidak hanya terfokus pada pengetahuan atau aspek kognitif saja, namun siswa juga dibekali dengan penanaman sikap yang menunjang kehidupan mendatang bagi mereka. Lebih khusus lagi tentang penanaman apresiasi nilai budaya bangsa kepada siswa untuk dapat tetap melestarikan budaya dan nilainilai di dalamnya. Hal ini berdasarkan peraturan Gubernur Nusa Tenggara Barat (NTB) nomor 51 tahun 2015 tentang program Wisata Halal yang di dalamnya termasuk mempersiapkan wisata budaya untuk menunjang pariwisata di Nusa Tenggara Barat. Sehingga sangat perlu ditanamkan sejak dini tentang nilai-nilai budaya dan penanaman apresiasi nilai budaya bangsa khususnya di Lombok dan NTB pada umumnya. Apresiasi nilai budaya bangsa merupakan bentuk penilaian dan penghargaan terhadap suatu budaya yang di dalamnya terdapat aspek pemahaman, kesenangan, ketertarikan, pemanfaatan, dan partisipasi dalam kegiatan budaya (Barret, 2007; Jarret, 1991; Pugh \& Phillips, 2011; Alexon \& Sukmadinata, 2010; Hardy, 2005). 
Pada kenyataannya, kebanyakan pembelajaran matematika di Indonesia masih fokus pada perhitungan (drill), peran guru lebih dominan (teacher-centered), siswa belum diberikan kesempatan dan didorong untuk menyampaikan pendapat (reasoning), tidak membangun pemahaman konsep, belum berorientasi pemecahan masalah, dan belum banyak dikaitkan dengan kehidupan sehari-hari (Wahyu \& Sofyan, 2016). Berkaitan dengan peran guru dalam pembelajaran, Sulianto (2009) menambahkan bahwa belajar matematika dari sumber guru merupakan hal yang banyak dilakukan selama ini, guru masih mendominasi pola interaksi edukatif dalam proses pembelajaran. Guru masih menjadi satusatunya sumber belajar bagi siswa. Hal ini membuat matematika menjadi pelajaran yang sulit bagi siswa dan memberikan dampak terhadap prestasi belajar matematika siswa. Lingkungan siswa belum dimanfaatkan oleh guru untuk membantu siswa dalam belajar matematika sehingga matematika masih terasa sulit dan sangat abstrak bagi siswa. Suhartini \& Santoso (2014) juga memberikan pandangan tentang sifat matematika yang sulit bagi siswa, yaitu karena matematika itu sendiri merupakan suatu ilmu yang membutuhkan suatu kemampuan dan penalaran dalam mempelajarinya.

Berdasarkan hasil wawancara dengan salah satu guru mata pelajaran matematika SMP Darul Hikmah Mataram, diperoleh juga bahwa dalam penyusunan perangkat pembelajaran masih sering mengadaptasi dari internet dan hasil MGMP. Metode pembelajaran yang digunakan pun masih menggunakan metode ceramah. Guru belum menggunakan hal-hal atau objek-objek yang dekat dengan kehidupan siswa seperti budaya Lombok yang lebih bersifat kontekstual. Hal ini menunjukkan perangkat pembelajaran di sekolah pada umumnya belum banyak yang memanfaatkan kehidupan sosial dan budaya siswa yang lebih bersifat kontekstual. Hal ini membuat nilai-nilai budya terasa sangat jauh dengan matematika, secara tidak langsung akan membentuk pikiran siswa tentang jauhnya keterkaitan matematika dengan kehidupan sehari-hari. Hal tersebut besar kemungkinan membuat matematika sulit untuk dipahami oleh siswa dalam proses pembelajaran di kelas. Hal ini berdampak pada belum optimalnya prestasi belajar matematika siswa. Belum optimalnya prestasi belajar matematika di Lombok dan provinsi Nusa Tenggara Barat (NTB) pada umumnya ditunjukkan oleh perolehan rata-rata nilai UN 
matematika berdasarkan data Balitbang Kemdikbud tahun 2012-2015 berikut.

Tabel 1. Rata-rata Nilai UN Matematika SMP Provinsi NTB

\begin{tabular}{|c|c|c|}
\hline No. & Tahun Ajaran & $\begin{array}{c}\text { Rata-rata Nilai UN } \\
\text { Matematika }\end{array}$ \\
\hline 1 & $2011-2012$ & 8,27 \\
\hline 2 & $2012-2013$ & 6,59 \\
\hline 3 & $2013-2014$ & 6,65 \\
\hline 4 & $2014-2015$ & 5,686 \\
\hline
\end{tabular}

(Balitbang Kemdikbud, 2012-2015)

Rata-rata nilai UN matematika yang diperoleh provinsi NTB pada Tabel 1 menunjukkan belum optimalnya prestasi belajar matematika SMP di Lombok dan NTB pada umumnya.

Hasil observasi di SMP Darul Hikmah, Kota Mataram, menunjukkan pembelajaran matematika masih bersifat teoritis dan tidak disajikan dalam bentuk yang kontekstual. Hal ini ditunjukkan oleh perangkat pembelajaran yang digunakan oleh guru matematika belum menggunakan pendekatan kontekstual sehingga di dalam proses pembelajaran matematika masih hanya sekedar teori yang berisikan angka-angka dan operasi perhitungan saja bagi siswa. Selain itu, perangkat pembelajaran yang digunakan belum mengaitkan aspek budaya Lombok di dalamnya seperti unsur geometris yang terdapat pada hasil kerajinan tangan dan kain Songket khas masyarakat Lombok, sehingga materi matematika dirasa masih jauh dari kehidupan peserta didik.

Terkait dengan penanaman apresiasi nilai budaya bangsa, sebagian masyarakat Indonesia tidak lagi mengaktualisasi nilai-nilai budaya bangsa seiring dengan gencarnya arus budaya asing yang masuk di Indonesia yang membuat nilai-nilai budaya bangsa mulai perlahan terlupakan (AhimsaPutra, 2002). Jika dicermati fenomena pada masyarakat Lombok dewasa ini utamanya kalangan muda mulai mengalami pengikisan nilai-nilai budaya. Kalangan muda Lombok pada umumnya cenderung kurang memperhatikan budayanya sendiri. Misalnya dalam acara-acara adat seperti sorong serah dan nyongkolan, kebanyakan pemuda tidak menggunakan atribut yang seharusnya digunakan seperti sapuq dan wes ewes yang merupakan identitas dari masyarakat Lombok itu sendiri. Selain itu kalangan muda Lombok dewasa ini tidak memiliki pengetahuan yang luas tentang budayanya sendiri. Sebagian besar kalangan muda tidak mengetahui adat-adat masyarakat Lombok seperti aturan-aturan dalam tradisi merariq seperti adanya denda jika merariq siang hari dan tentang 
pisuke dalam merariq. Hal-hal seperti ini menunjukkan apresiasi terhadap budaya sendiri mulai terkikis, sehingga penanaman apresiasi nilai budaya bangsa menjadi penting untuk diperhatikan.

Lingkungan merupakan faktor yang mempengaruhi proses belajar siswa. Salah satu pendekatan pembelajaran yang dapat membantu siswa belajar dengan mengaitkan kehidupan sehari-hari siswa serta berkaitan erat dengan budaya serta kebiasaan siswa adalah pendekatan kontekstual (contextual teaching and learning). Hal ini sesuai dengan penjelasan Johnson (2002) yang mengatakan bahwa pendekatan kontekstual merupakan suatu pendekatan pembelajaran yang membantu siswa untuk belajar dengan cara menghubungkan materi yang dipelajari dengan kehidupan sehari-hari siswa, baik personal, lingkungan sosial, dan budaya. Pendekatan kontekstual mampu menyajikan proses belajar yang lebih bermakna karena dimulai dari pengetahuan dan pengalaman yang telah ada pada diri siswa kemudian dikaitkan dengan materi yang sedang dipelajari (Johnson, 2002).

Lingkungan sekitar merupakan tempat awal dari proses belajar dan berpikir dari tiap individu. Di dalamnya terdapat budaya dan kebiasaan yang sangat akrab bagi masing-masing individu dalam lingkungan tersebut. Demikian juga dengan siswa dan matematika, proses pembelajaran akan lebih bermakna jika matematika dapat disajikan dalam hal-hal yang dekat dengan kehidupan siswa seperti kebudayaan dan kebiasaan dalam lingkungan siswa. Hal ini diperkuat dengan hasil penelitian Sulistyawati (2015) yang menyatakan bahwa pendekatan kontekstual berbasis budaya lokal efektif ditinjau dari aspek prestasi belajar, minat belajar matematika, dan apresiasi siswa terhadap matematika.

Berdasarkan hal tersebut, perlu dikembangkan suatu perangkat pembelajaran matematika dengan pendekatan kontekstual budaya, khususnya budaya Lombok, sehingga proses pembelajaran matematika khususnya di Lombok dapat lebih bermakna karena menggunakan hal-hal yang dekat dengan kehidupan siswa seperti budaya dan kebiasaan masyarakat setempat. Selain itu, pengembangan perangkat pembelajaran seperti ini diharapkan pula dapat meningkatkan apresiasi siswa terhadap budaya daerah sendiri. Dengan demikian, pembelajaran matematika tidak hanya menyangkut angka dan operasi hitung semata serta tidak semata melihat aspek kognitif saja, namun pembelajaran matematika dapat memberikan dampak sosial budaya kepada para peserta didik.

Berdasarkan permasalahan yang telah diuraikan berikut kajian teorinya maka penelitian ini bertujuan untuk menghasilkan dan mendeskripsikan karakteristik perangkat pembelajaran matematika SMP 
dengan pendekatan kontekstual budaya Lombok berorientasi pada prestasi dan apresiasi nilai budaya bangsa yang valid, praktis, dan efektif.

\section{B. Metode Penelitian}

Penelitian ini adalah penelitian pengembangan dengan menggunakan model ADDIE yang terdiri dari tahapan: (1) analysis (analisis) mencakup analisis kebutuhan, analisis siswa, dan analisis materi; (2) design (desain) mencakup desain produk yang dikembangkan; (3) development (pengembangan) mencakup pengembangan produk dan validasi ahli; (4) implementation (implementasi) mencakup uji coba produk di lapangan; dan (5) evaluation (evaluasi) mencakup analisis kepraktisan dan keefektivan produk berdasarkan hasil uji coba lapangan. Penelitian ini dilaksanakan pada bulan 29 April - 27 Mei 2016 bertempat di SMP Darul Hikmah Mataram. Adapun subjek uji coba pada penelitian ini adalah guru dan siswa kelas VII SMP Darul Hikmah Mataram.

\section{Prosedur Pengembangan}

Prosedur pengembangan diawali dengan tahap Analysis yaitu tahap penelitian pendahuluan yang bertujuan untuk memperoleh informasi yang berkaitan dengan masalah di lapangan dan produk yang akan dikembangkan sebagai solusi dari masalah tersebut. Pada tahap ini juga dilakukan tinjauan pustaka mengenai konsep dan teori yang berkaitan dengan prestasi, dan apresiasi nilai budaya bangsa sebagai dasar untuk menyusun indikator dan kajian mengenai teori belajar yang tepat sehingga diperoleh pendekatan pembelajaran yang relevan. Selain itu juga dilakukan analisis dan telaah kurikulum matematika SMP kelas VII sebagai dasar untuk menentukan KI dan KD yang akan digunakan dalam pengembangan perangkat pembelajaran.

Tahapan berikutnya adalah tahap Design yaitu perancangan produk yang mencakup penyusunan Rencana Pelaksanaan Pembelajaran (RPP) dan Lembar Kegiatan Siswa (LKS) dengan pendekatan kontekstual budaya Lombok serta penyusunan instrumen tes prestasi dan angket apresiasi nilai budaya bangsa.

Prosedur berikutnya yaitu tahap Development yakni pengembangan produk perangkat pembelajaran berupa RPP dan LKS dengan pendekatan kontekstual budaya Lombok dan penyusunan perangkat penilaian berupa 
lembar penilaian guru, lembar penilaian siswa, angket apresiasi nilai budaya bangsa dan tes prestasi. Dalam tahap ini juga dilakukan validasi oleh ahli. Pada tahap validasi revisi produk dilakukan berdasarkan masukan dan saran dari ahli. Apabila hasil analisis produk awal perangkat pembelajaran dinyatakan layak digunakan tanpa revisi, maka produk dapat langsung diujicobakan. Apabila hasil validasi dinyatakan layak digunakan dengan revisi, maka dilakukan revisi seperti yang disarankan ahli yang selanjutnya menghasilkan produk awal yang layak digunakan.

Selanjutnya pada tahap Implementation dilakukan uji coba lapangan untuk mengetahui kualitas kepraktisan dan keefektivan produk yang dikembangkan. Tahap ini dilakukan ujicoba di SMP Darul Hikmah Mataram, Nusa Tenggara Barat.

Tahap akhir yakni tahap Evaluation dilakukan analisis hasil uji coba lapangan. Apabila hasil analisis data telah memenuhi kriteria yang ditentukan, maka produk tersebut adalah produk akhir, jika hasil analisis menunjukkan belum memenuhi kriteria, maka dilakukan revisi produk kembali sehingga diperoleh produk yang valid, praktis, dan efektif.

\section{Teknik dan Instrumen Pengumpulan Data}

Teknik pengumpulan data yang digunakan ada dua, yaitu teknik tes dan teknik non-tes. Teknik pengumpulan data dengan tes menggunakan instrumen tes prestasi belajar matematika siswa. Teknik non-tes menggunakan lembar validasi, lembar penilaian guru, lembar penilaian siswa, lembar observasi keterlaksanaan pembelajaran, dan angket apresiasi nilai budaya bangsa. Lembar validasi digunakan untuk mengukur kevalidan perangkat pembelajaran yang dikembangkan melalui penilaian oleh ahli, yang terdiri atas lembar validasi RPP dan lembar validasi LKS. Lembar penilaian guru, lembar penilaian siswa, dan lembar observasi keterlaksanaan pembelajaran digunakan untuk mengukur kepraktisan perangkat pembelajaran. Sedangkan instrumen tes prestasi dan apresiasi nilai budaya bangsa digunakan untuk mengukur keefektivan perangkat. Instrumen tes prestasi terdiri atas soal pilihan ganda.

\section{Teknik Analisis Data}

Teknik analisis data dilakukan untuk mendapatkan produk perangkat pembelajaran dengan pendekatan kontekstual budaya Lombok yang berkualitas dan memenuhi aspek kevalidan, kepraktisan, dan keefektivan. 
Pada penelitian ini pedoman kualitas kevalidan menggunakan klasifikasi interpretasi penilaian kevalidan seperti pada Tabel 2.

Tabel 2. Kategori Kevalidan RPP dan LKS

\begin{tabular}{|c|c|c|}
\hline Interval Skor RPP & $\begin{array}{c}\text { Interval } \\
\text { Skor LKS }\end{array}$ & Kategori \\
\hline$X>202$ & $X>90$ & Sangat Baik \\
\hline $180<X \leq 202$ & $80<X \leq 90$ & Baik \\
\hline $157<X \leq 180$ & $70<X \leq 80$ & Cukup \\
\hline $122<X \leq 157$ & $55<X \leq 70$ & Kurang \\
\hline$X \leq 122$ & $X \leq 55$ & Sangat Kurang \\
\hline
\end{tabular}

Perangkat pembelajaran matematika dengan pendekatan kontekstual budaya Lombok dikatakan valid jika rata-rata penilaian ahli minimal dalam kategori "baik" untuk masing-masing perangkat pembelajaran (RPP dan LKS).

Analisis kepraktisan perangkat diperoleh berdasarkan analisis data hasil lembar penilaian guru, lembar penilaian siswa, dan lembar observasi keterlaksanaan pembelajaran. Skor penilaian guru terhadap perangkat pembelajaran (RPP dan LKS), skor penilaian siswa terhadap perangkat pembelajaran (LKS), dan persentase keterlaksanan pembelajaran dikonversi menjadi data kualitatif sesuai dengan Tabel 3. Perangkat pembelajaran yang dikembangkan dikatakan praktis jika penilaian guru, penilaian siswa, dan observasi keterlaksanaan pembelajaran minimal dalam kategori "baik".

Tabel 3. Kategori untuk Aspek Kepraktisan

\begin{tabular}{|c|c|c|c|}
\hline \multicolumn{3}{|c|}{ Interval Skor } & \multirow[b]{2}{*}{ Kategori } \\
\hline $\begin{array}{c}\text { Penilaian } \\
\text { Guru }\end{array}$ & Penilaian Siswa & $\begin{array}{c}\text { Observasi } \\
\text { Keterlaksanaan } \\
\text { Pembelajaran }\end{array}$ & \\
\hline$x>54$ & $x>31,5$ & $90 \%<p \leq 100 \%$ & Sangat Baik \\
\hline $45<X \leq 54$ & $28<x \leq 31,5$ & $80 \%<p \leq 90 \%$ & Baik \\
\hline $37<x \leq 45$ & $24,5<x \leq 28$ & $70 \%<p \leq 80 \%$ & Cukup \\
\hline $33<x \leq 37$ & $19,25<x \leq 24,5$ & $55 \%<p \leq 70 \%$ & Kurang \\
\hline$x \leq 33$ & $x \leq 19,25$ & $p \leq 55 \%$ & Sangat Kurang \\
\hline
\end{tabular}

Analisis data untuk menentukan keefektivan perangkat dilakukan dengan menganalisis data hasil tes prestasi dan data hasil angket apresiasi nilai budaya bangsa. Kriteria keefektifan berdasarkan hasil tes prestasi 
belajar ditentukan dengan persentase jumlah siswa yang mencapai KKM. Perangkat pembelajaran dikatakan efektif jika persentase jumlah siswa yang mencapai $\mathrm{KKM} \geq 80 \%$.

Selanjutnya adalah analisis keefektivan berdasarkan perolehan skor angket apresiasi nilai budaya bangsa. Kriteria keefektivan berdasarkan hasil angket apresiasi nilai budaya bangsa ditentukan dengan melakukan konversi skor angket siswa sesuai dengan Tabel 4.

Tabel 4. Kategori Apresiasi Nilai Budaya Bangsa

\begin{tabular}{|c|c|}
\hline Interval Skor & Kategori \\
\hline$X>84$ & Sangat Tinggi \\
\hline $68<X \leq 84$ & Tinggi \\
\hline $52<X \leq 68$ & Sedang \\
\hline $36<X \leq 52$ & Rendah \\
\hline$X \leq 36$ & Sangat Rendah \\
\hline
\end{tabular}

Perangkat pembelajaran yang dikembangkan dikatakan efektif jika: (1) total skor angket apresiasi nilai budaya sesudah menggunakan perangkat pembelajaran dengan pendekatan kontekstual budaya Lombok lebih dari total skor angket sebelumnya; dan (2) skor angket siswa menunjukkan minimal $80 \%$ siswa berada pada kategori tinggi dan sangat tinggi.

\section{Temuan dan Pembahasan}

\section{Hasil Pengembangan Produk Awal}

Produk awal yang dikembangkan berupa perangkat pembelajaran matematika yang terdiri dari RPP dan LKS. Karakteristik dari RPP yang dikembangkan yaitu: (1) tujuan pembelajaran mengarah kepada pencapaian prestasi belajar matematika dan penanaman apresiasi nilai budaya bangsa pada siswa; (2) kegiatan pembelajaran memuat langkahlangkah pendekatan kontekstual budaya Lombok yang terdiri atas relating (menghubungkan), experiencing (mengalami), applying (menerapkan), cooperating (bekerjasama), dan transferring (mentransfer); dan (3) RPP yang dikembangkan memuat konteks budaya Lombok.

LKS yang dikembangkan memiliki karakteristik yaitu: (1) konten LKS memuat konteks budaya Lombok yang terkait materi matematika; (2) LKS 
yang digunakan untuk menemukan konsep matematika dengan konteks budaya Lombok; (3) LKS yang dikembangkan disusun sesederhana mungkin untuk mengakomodasi nilai kepraktisan dari LKS tersebut; (4) pemberian masalah pada LKS berkaitan dengan konteks budaya Lombok; dan (5) dalam pelaksanaannya, hasil kerja siswa dalam LKS dinilai oleh guru untuk melihat proses dalam pembelajaran yang dilakukan siswa.

2. Hasil Uji Coba Produk

Data kevalidan dari perangkat pembelajaran yang dikembangkan (RPP dan LKS) diperoleh berdasarkan penilaian para ahli. Penilaian ini dilakukan oleh dua orang ahli dalam bidang pembelajaran matematika. Hasil penilaian ahli terhadap kevalidan RPP dan LKS disajikan pada Tabel 5.

Tabel 5. Hasil Analisis Kevalidan Perangkat Pembelajaran

\begin{tabular}{|c|c|c|c|c|}
\hline \multirow{2}{*}{ Validator } & \multicolumn{2}{|c|}{ RPP } & \multicolumn{2}{c|}{ LKS } \\
\cline { 2 - 5 } & Total Skor & Kategori & Total Skor & Kategori \\
\hline I & 199 & SB & 84 & B \\
\hline II & 170 & CB & 85 & B \\
\hline Rata-rata & $\mathbf{1 8 4 , 5}$ & B & $\mathbf{8 4 , 5}$ & B \\
\hline
\end{tabular}

Tabel 5 menunjukkan rata-rata total skor penilaian ahli terhadap RPP yang dikembangkan adalah 184,5 dengan kategori "baik" dan rata-rata total skor penilaian ahli terhadap LKS yang dikembangkan adalah 84,5 dengan kategori "baik". Hal ini menunjukkan bahwa baik RPP dan LKS yang dikembangkan sudah valid.

Penilaian kualitas produk ditinjau dari aspek kepraktisan berdasarkan tiga sumber, yaitu lembar penilaian guru, lembar penilaian siswa, dan lembar observasi keterlaksanaan pembelajaran. Lembar penilaian guru terdiri dari penilaian guru terhadap RPP dan penilaian guru terhadap LKS. Guru yang memberikan penilaian terdiri dari dua orang guru matematika. Hasil penilaian guru terhadap RPP dan LKS disajikan pada Tabel 6.

Tabel 6. Hasil Analisis Penilaian Guru

\begin{tabular}{|c|c|c|c|}
\hline \multirow{2}{*}{ Produk } & \multicolumn{2}{|c|}{ Skor Penilaian } & \multirow{2}{*}{ Rerata } \\
\cline { 2 - 3 } & Guru 1 & Guru 2 & \\
\hline RPP & 21 & 25 & 23 \\
\hline LKS & 21 & 26 & 23,5 \\
\hline Total & $\mathbf{4 2}$ & $\mathbf{5 1}$ & $\mathbf{4 6 , 5}$ \\
\hline Kesimpulan & \multicolumn{3}{|c}{ Baik } \\
\hline
\end{tabular}


Tabel 6 menunjukkan bahwa rata-rata skor penilaian yang diberikan dua orang guru adalah 46,5 dengan kategori "baik". Hal ini menunjukkan bahwa RPP dan LKS yang dikembangkan memenuhi kriteria praktis berdasarkan penilaian guru.

Lembar penilaian siswa berisi penilaian siswa terhadap LKS yang dikembangkan. Hasil penilaian siswa terhadap LKS yang dikembangkan menunjukkan bahwa rata-rata skor penilaian siswa adalah 29,43 dengan kategori "baik". Hal ini menunjukkan bahwa perangkat pembelajaran (LKS) yang dikembangkan memenuhi kriteria praktis berdasarkan penilaian siswa.

Data keterlaksanaan pembelajaran yang diperoleh melalui lembar observasi yang diisi oleh observer disajikan pada Tabel 7.

Tabel 7. Hasil Observasi Keterlaksanaan Pembelajaran

\begin{tabular}{|c|c|c|c|}
\hline $\begin{array}{c}\text { Pertemuan } \\
\text { ke - }\end{array}$ & $\begin{array}{c}\text { Rata-rata skor } \\
\text { (keg. guru dan siswa) }\end{array}$ & $\%$ & Kategori \\
\hline I & 16 & $80 \%$ & Cukup \\
\hline II & 17,5 & $88 \%$ & Baik \\
\hline III & 16,5 & $83 \%$ & Baik \\
\hline IV & 17,5 & $88 \%$ & Baik \\
\hline V & 18 & $90 \%$ & Baik \\
\hline \multicolumn{2}{|c|}{ Rata-rata } & $\mathbf{8 6 \%}$ & Baik \\
\hline
\end{tabular}

Tabel 7 menunjukkan rata-rata persentase keterlaksanaan pembelajaran mencapai $86 \%$ dengan kategori "baik". Hal ini menunjukkan perangkat pembelajaran yang dikembangkan memenuhi kriteria praktis berdasarkan observasi keterlaksanaan pembelajaran.

Data keefektivan diperoleh dari hasil tes prestasi belajar matematika siswa dan angket apresiasi nilai budaya bangsa. Data hasil tes prestasi belajar matematika siswa disajikan pada Tabel 8 .

Tabel 8. Hasil Tes Prestasi Belajar Matematika Siswa

\begin{tabular}{|c|l|c|}
\hline No. & \multicolumn{1}{|c|}{ Keterangan } & Kelas VII \\
\hline 1. & Banyak siswa & 34 \\
\hline 2. & Nilai tertinggi & 85 \\
\hline 3. & Nilai terendah & 50 \\
\hline 4. & Rata-rata nilai & 76,76 \\
\hline 5. & Tuntas KKM & 30 \\
\hline 6. & Tidak tuntas KKM & 4 \\
\hline 7. & Persentase ketuntasan & $88,24 \%$ \\
\hline
\end{tabular}


Berdasarkan keterangan pada Tabel 8, persentase siswa yang telah mencapai KKM adalah 88,24\%. Hal ini menunjukkan perangkat pembelajaran matematika yang dikembangkan efektif ditinjau dari prestasi belajar matematika siswa karena telah memenuhi kriteria keefektifan minimal $80 \%$ siswa telah mencapai KKM.

Penilaian kualitas keefektivan selanjutnya didasarkan pada hasil angket apresiasi nilai budaya bangsa sebelum dan setelah pembelajaran. Data hasil angket sebelum dan sesudah pembelajaran disajikan pada Tabel 9.

Tabel 9. Skor angket sebelum dan sesudah pembelajaran

\begin{tabular}{|c|c|c|}
\hline Aspek Angket & Sebelum & Sesudah \\
\hline Total Skor & 2285 & 2595 \\
\hline Rata-rata Skor & 67,21 & 76,32 \\
\hline
\end{tabular}

Tabel 9 menunjukkan bahwa total skor maupun rata-rata skor angket sesudah proses pembelajaran lebih tinggi dari total skor dan rata-rata skor angket sebelum pembelajaran.

Sementara itu persentase hasil angket apresiasi nilai budaya bangsa disajikan pada Tabel 10.

Tabel 10. Persentase Hasil Angket Apresiasi Nilai Budaya Bangsa

\begin{tabular}{|r|c|c|c|}
\hline \multirow{2}{*}{ Interval Skor } & \multirow{2}{*}{ Kategori } & \multicolumn{2}{|c|}{ Kelas VII (N=34) } \\
\cline { 3 - 4 } & & Banyak Siswa & Persentase \\
\hline $\mathrm{X}>84$ & Sangat Tinggi & 3 & $8,82 \%$ \\
\hline $68<\mathrm{X} \leq 84$ & Tinggi & 25 & $73,53 \%$ \\
\hline $52<\mathrm{X} \leq 68$ & Sedang & 6 & $17,65 \%$ \\
\hline $36<\mathrm{X} \leq 52$ & Rendah & 0 & $0 \%$ \\
\hline $\mathrm{X} \leq 36$ & Sangat Rendah & 0 & $0 \%$ \\
\hline
\end{tabular}

Berdasarkan Tabel 10, persentase siswa yang berada pada kategori tinggi adalah $73,53 \%$ dan siswa yang berada pada kategori sangat tinggi adalah $8,82 \%$, sehingga persentase siswa yang berada pada kategori "tinggi" dan "sangat tinggi" adalah $82,35 \%(\geq 80 \%)$.

Jadi, perangkat pembelajaran yang dikembangkan memenuhi kriteria efektif ditinjau dari apresiasi nilai budaya bangsa karena total skor angket pembelajaran lebih tinggi dari total skor angket sebelum pembelajaran, serta telah memenuhi kriteria minimal $80 \%$ siswa berada pada kategori "tinggi" dan "sangat tinggi". 


\section{Kajian Produk Akhir}

Pengembangan perangkat pembelajaran matematika dalam penelitian ini telah dilakukan melalui tahapan-tahapan dalam model pengembangan ADDIE yaitu analysis (analisis), design (desain), development (pengembangan), implementation (implementasi), dan evaluation (evaluasi). Melalui tahapan-tahapan tersebut peneliti dapat mengetahui kualitas dari perangkat pembelajaran yang dikembangkan, yaitu harus memenuhi kriteria kevalidan, kepraktisan, dan keefektivan (Nieveen, 1999). Berdasarkan hasil validasi ahli dan uji coba lapangan diketahui bahwa perangkat pembelajaran yang dikembangkan telah memenuhi kriteria valid, praktis, dan efektif ditinjau dari prestasi belajar matematika dan apresiasi nilai budaya bangsa siswa.

Berdasarkan proses pelaksanaan di lapangan, hasil observasi keterlaksanaan pembelajaran menunjukkan bahwa keterlaksanaan pembelajaran termasuk dalam kategori "baik". Meskipun demikian, dalam proses pembelajaran, ada beberapa langkah yang masih sulit terlaksana berdasarkan pengamatan observer, seperti pemberian motivasi belajar kepada siswa yang terlihat menurun tiap pertemuannya. Hal ini disebabkan karena beberapa pertemuan terakhir berisi materi yang merupakan pengembangan dari materi sebelumnya seperti materi interpretasi tabel, diagram batang, diagram lingkaran dan grafik garis yang terkait masalah nyata. Materi tersebut merupakan penerapan dari materi sebelumnya seperti penyajian data dalam bentuk tabel, diagram batang, diagram lingkaran, dan grafik garis. Hal ini membuat guru merasa pemberian contoh untuk memotivasi siswa tidak perlu untuk diulang.

Selain itu, langkah pembelajaran yang tampak sulit terlaksana adalah kegiatan merefleksi pembelajaran. Hal ini terjadi karena pengaturan waktu yang belum optimal dalam proses pembelajaran. Pada beberapa pertemuan awal terlihat kegiatan refleksi tidak dapat terlaksana, meskipun pada pertemuan terakhir guru dalam melakukan refleksi terhadap materi yang dipelajari.

Sementara itu, efektifnya perangkat pembelajaran matematika SMP dengan pendekatan kontekstual ini karena dalam proses pembelajarannya siswa diberikan permasalahan yang bersifat kontekstual dalam hal ini berkaitan dengan budaya Lombok yang merupakan budaya mereka sendiri. Hal ini menyebabkan pembelajaran matematika menjadi 
lebih mudah bagi siswa dan pembelajaran menjadi lebih bermakna karena pembelajaran diawali dari hal yang mereka ketahui sebelumnya. Hal ini sesuai dengan pendapat Johnson (2002) yang menjelaskan bahwa pendekatan pembelajaran kontekstual mampu menyajikan proses pembelajaran yang bermakna bagi siswa.

Pada awal pembelajaran siswa diberikan permasalahan tekait budaya Lombok yang kemudian akan dihubungkan dengan materi matematika yang akan dipelajari siswa (tahap relating). Setelah itu siswa juga diberikan kesempatan untuk memecahkan permasalahan yang ada (tahap experiencing) sehingga siswa tidak hanya pasif menerima informasi atau ceramah dari guru. Siswa juga diberikan kesempatan untuk mencoba mengaplikasikan pengetahuan atau informasi yang telah ditemukan untuk memecahkan permasalahan yang diberikan guru (tahap applying). Proses pembelajaran pun memberikan kesempatan kepada siswa untuk dapat bekerjasama dan belajar dalam kelompok untuk dapat mengeluarkan pendapat serta belajar mendengarkan pendapat temannya (tahap cooperating). Selain itu setelah proses pembelajaran siswa ditantang untuk menggunakan pengetahuannya untuk memecahkan permasalahan yang lain dalam hal ini berkaitan dengan budaya Lombok yang lain (tahap transferring).

Proses pembelajaran menggunakan pendekatan kontekstual akan memberikan pemahaman yang lebih dalam bagi siswa tentang materi matematika yang dipelajari. Hal ini membuat siswa lebih mengerti tentang materi matematika karena dapat melakukan penemuan sendiri dengan pengetahuan yang telah ada pada diri siswa (budaya Lombok). Selain itu proses pembelajaran yang menggunakan budaya Lombok membuat siswa merasa lebih dekat dan akrab dengan budaya sendiri, sehingga apresiasi siswa tentang budaya Lombok akan lebih tinggi.

\section{Simpulan}

Perangkat pembelajaran matematika dengan pendekatan kontekstual budaya Lombok yang berorientasi pada prestasi belajar matematika dan apresiasi nilai budaya bangsa memiliki karakteristik sebagai berikut: (a) kegiatan pembelajaran memuat langkah-langkah pendekatan kontekstual budaya Lombok yang terdiri dari relating, experiencing, applying, cooperating, dan transferring; (b) memuat konteks 
budaya Lombok; dan (c) menggunakan instrumen untuk mengukur apresiasi nilai budaya bangsa.

Perangkat pembelajaran matematika SMP dengan pendekatan kontekstual budaya Lombok berorientasikan prestasi belajar matematika dan apresiasi nilai budaya bangsa siswa kelas VII dikembangkan menggunakan model pengembangan ADDIE (Analysis, Design, Development, Implementation, and Evaluation). Perangkat pembelajaran matematika SMP dengan pendekatan kontekstual budaya Lombok berorientasikan prestasi belajar matematika dan apresiasi nilai budaya bangsa siswa kelas VII yang terdiri dari RPP dan LKS telah memenuhi kriteria valid, praktis, dan efektif.

\section{Daftar Pustaka}

Ahimsa-Putra, H. S. (2002). Aktualisasi nilai budaya bangsa di kalangan generasi muda. Jurnal Ketahanan Nasional, 6 (3), $45-55$.

Alexon \& Sukmadinata, N. S. (2010). Pengembangan model pembelajaran terpadu berbasis budaya untuk meningkatkan apresiasi siswa terhadap budaya lokal. Cakrawala Pendidikan, Jurnal Ilmiah Pendidikan, 2, 189 203.

Balitbang Kemdikbud. (2012). Panduan pemanfaatan hasil UN tahun pelajaran 2011/2012 untuk perbaikan mutu pendidikan. Jakarta: PUSPENDIK.

Balitbang Kemdikbud. (2013). Panduan pemanfaatan hasil UN tahun pelajaran 2012/2013 untuk perbaikan mutu pendidikan. Jakarta: PUSPENDIK.

Balitbang Kemdikbud. (2014). Panduan pemanfaatan hasil UN tahun pelajaran 2013/2014 untuk perbaikan mutu pendidikan. Jakarta: PUSPENDIK.

Balitbang Kemdikbud. (2015). Panduan pemanfaatan hasil UN tahun pelajaran 2014/2015 untuk perbaikan mutu pendidikan. Jakarta: PUSPENDIK.

Barret, T. (2007). Teaching toward appreciation. Dalam L. Bresler (Eds.), International handbook of research of arts educatiosn (pp. 639-654). New York, USA: Springer.

Gubernur NTB. (2015). Peraturan Gubernur Nusa Tenggara Barat Nomor 51, Tahun 2015, tentang Wisata Halal.

Hardy, G. H. (2005). A mathematician's apology. Alberta: University of Alberta Mathematical Sciences Society. 
Jarret, L. J. (1991). The teaching of values: Caring and appreciation. New York, USA: Routledge.

Johnson, E. B. (2002). Contextual teaching and learning: What it is and why it's here to stay. Thousand Oaks, USA: Corwin Press, Inc.

Mendikbud. (2014). Peraturan Menteri Pendidikan dan Kebudayaan Nomor 103, Tahun 2014, tentang pembelajaran pada pendidikan dasar dan pendidikan menengah: Pedoman pelaksanaan pembelajaran.

Nieveen, N. (1999). Prototyping to reach product quality. Dalam Van den Akker, J., et al., Design approaches and tools in education and training (pp. 125-136). Dordrecht: Kluwer Academic Publishers.

Pugh, K. J. \& Phillips, M. M. (2011). Helping students develop an appreciation for school content. Theory into practice, 50 (4), 285-292.

Suhartini, S., \& Santoso, R. (2014). Pengembangan perangkat pembelajaran matematika untuk siswa SMK jurusan akuntansi di Sleman dengan pendekatan pembelajaran kontekstual. Jurnal Riset Pendidikan Matematika, 1(1), 69-76. DOI:http://dx.doi.org/10.21831/jrpm.v1i1.2665

Sulianto, J. (2009). Keefektifan model pembelajaran kontekstual dengan pendekatan open-ended dalam aspek penalaran dan pemecahan masalah pada materi segitiga di kelas VII. Pythagoras: Jurnal Pendidikan Matematika, 5(2), 73-86. DOI:http://dx.doi.org/10.21831/pg.v5i2.547

Sulistyawati, E. (2015). Keefektifan pembelajaran lingkaran dengan pendekatan kontekstual berbasis budaya lokal ditinjau dari prestasi belajar, minat belajar, dan apresiasi siswa terhadap matematika siswa SMP kelas VIII (Tesis). Diakses di http://eprints.uny.ac.id/21353/

Wahyu, K., \& Mahfudy, S. (2016). Sejarah Matematika: Alternatif Strategi Pembelajaran Matematika. Beta Jurnal Tadris Matematika, 9(1), 89-110. DOI: http://dx.doi.org/10.20414/betajtm.v10i1.83 